\title{
Erratum to: Mixité sociale et choix modal : importance des dimensions symboliques dans l'attrait des transports collectifs
}

Erratum to: Social diversity and transport mode choice: the importance of symbolic dimensions in the attractiveness of mass transit

\author{
X. Brisbois · D.R. Kouabenan • L. Rubens
}

C IFSTTAR et Springer-Verlag France 2013

Erratum to : Rech. Transp. Secur. DOI 10.1007/s13547-012-0044-6

Le titre correct de cet article est : « Mixité sociale et choix modal : importance des dimensions symboliques dans l'attrait des transports collectifs ». 